\section{VARIED THRUSH AT BIGGAR, SASKATCHEWAN}

ROBERT WAPPLE, Box 1045, Biggar, Saskatchewan. SOK OMO

On 1 October 1983 I decided to go bird-watching at one of our favorite locations in Biggar. At approximately 1500 , I was riding my bike down a back alley when I stopped at a fenceline between the last two yards at the east end of the lane. In one yard, (the furthest east), were about 30 American Robins and 3 White-throated Sparrows foraging on the ground among some fallen leaves and crab-apples. I was just glancing over into the other yard when I noticed a peculiar bird on the ground in a familiar robin-like stance.

Upon further study of the "robin", I suddenly realized that I was looking at a male Varied Thrush! The following field marks were obtained from ten $m$ as it faced me: robin size; bright orange stripe above the eye; very prominent black band across its bright orange breast and dull orange wingbars. After about ten minutes, the bird took flight to a nearby maple tree, where two low-pitched "chucks" were heard. The bird then flew down into the yard on the right and associated with the flock of robins. I noticed no aggressive behavior between the two species. While foraging, the thrush wasn't as active as the robins; it acted more like a Fox Sparrow than a thrush as it kicked up dead leaves and other vegetation in search of food. The bird at all times appeared to be somewhat more alert than the robins, often flying away to nearby shrubs at any unusual noise. It was studied for about twenty minutes at distances from three to twenty metres. A return visit to the area at 1800 failed to turn up the thrush.

On the afternoon of 2 October, it was again observed by myself and later that evening by Chris Escott, a birder from Saskatoon, in the same yard. The thrush was noted briefly during the early afternoon of 3 October by my brother Guy, who obtained several slides in the course of a thirty minute study. The bird was not seen on succeeding days.

The Varied Thrush is a rare but regular transient in Saskatchewan. In the Rosetown-Biggar study area there have been four previous sightings, including the first specimen record for the province. The most recent local observation was a single male in Valley Centre, about $40 \mathrm{~km}$ southeast of Biggar, on 25 April 1969.

\section{WATCH FOR COLOUR BANDED GYRFALCONS}

During summer 1983, 36 nestling Gyrfalcons were color banded in the Northwest Territories from Coppermine in the west-central N.W.T. to Cape Dorset on South Baffin Island. In addition to the regular U.S. Fish and Wildlife Service band, each nestling received from one to three coloured aluminum leg bands with all members of a brood receiving the same combination. The bands are about $10 \mathrm{~mm}$ wide, no more than two bands on each leg. Colours used were red, blue and black, and the sequence (top/bottom)and leg(left/right) are significant.

Observations should be sent to the Bird Banding Office, Canadian Wildlife Service, Ottawa, K1A OE7 and/or Robert G. Bromley, Bird of Prey Biologist, N.W.T. Wildlife Service, Yellowknife, N.W.T. X1A 2L9. 